\title{
RANCANG BANGUN DATA PENJUALAN SPAREPART DAN SERVICE PADA BENGKEL ASTRA MOTOR JAKARTA
}

\author{
Rizki Eka MawarDewi ${ }^{1}$, Wanti Rahayu ${ }^{2}$ \\ Program Studi Teknik Informatika, Fakultas Teknik dan Ilmu Komputer, \\ Universitas Indraprasta PGRI \\ Jalan Raya Tengah No 80, Kelurahan Gedong, Pasar Rebo, Jakarta Timur \\ ekamawarrizki@gmail.com¹,wanti.unindra27@gmail.com²
}

\begin{abstract}
Abstrak
Sistem informasi pengolahan data penjualan sparepart dan service merupakan suatu hal penting dalam mengelola sebuah instansi. Penelitian bertujuan untuk merancang sebuah aplikasi sistem informasi pengolahan data penjualan sparepart dan service pada bengkel Astra Motor Jakarta Berbasis Java, memberikan siklus sistem yang baru tentang proses pengolahan data sparepart dan service pada Astra Motor Jakarta serta untuk memberikan laporan penjualan sparepart dan service dengan cepat dan akurat melalui sebuah sistem aplikasi Metode penelitian yang digunakan adalah metode grounded (grounded research) yaitu suatu metode penelitian berdasarkan pada fakta dan menggunakan analisis di lapangan dengan tujuan untuk mengetahui proses persedian barang yang dilakukan selama ini. Setelah peneliti menganalisis sistem informasi pengolahan data penjulana sparepart dan service peneliti dapat menarik kesimpulan bahwa Bengkel Astra Motor Jakarta harus menerapkan suatu sistem untuk mengelola data sparepart dan service. Program ini dibuat dengan menggunakan perangkat lunak XAMPP dan NetBeans IDE 8.0.2 serta database $M y S Q L$. Program ini berfungsi untuk mengolah data sparepart service dan data transaksi Bengkel Astra Motor Jakarta. Dengan adanya sistem informasi pengolahan data penjualan sparepart dan service pada Bengkel Astra Motor Jakarta, semua proses yang berhubungan dengan data mekanik, data pelanggan, data kendaraan, transaksi service motor, data pemasok, data sparepart, tambah stok sparepart, transaksi penjualan sparepart serta report tidak lagi dilakukan secara manual.
\end{abstract}

Kata Kunci: Penjualan, Sparepart, Service, Java NetBeans, MySQL

\begin{abstract}
Information system processing data sales spare parts and services is an important thing in managing an agency. Research aims to design an information system application for the processing of spare parts and service data data at Astra Motor Jakarta Java-based workshop, provide a new system cycle about the process of processing spare parts and service data at Astra Motor Jakarta and to provide reports on spare parts and service sales quickly and accurately through an application system The research method used is a grounded research method. Research is based on facts and uses analysis in the field with the aim to find out the process of supplying goods carried out during this time. After the researcher analyzes the information system processing data sales spare parts and service researchers can draw the conclusion that Astra Motor Jakarta Workshop must implement a system to manage spare parts and service data. The program was created using XAMPP and NetBeans IDE 8.0.2 software as well as MySQL databases. This program serves to process spare parts service data and transaction data of Astra Motor Jakarta Workshop. With the information system processing spare parts sales and service data at Astra Motor Jakarta Workshop, all processes related to mechanical data, customer data, vehicle data, motor service transactions, supplier data, spare parts data, spare parts stock, spare parts sales transactions and reports are no longer done manually.
\end{abstract}

Keywords: Sales, Sparepart, Service, Java NetBeans, MySQL

\section{PENDAHULUAN}

Dalam dunia otomotif, kegiatan bisnis seperti service motor, penjualan dan pembelian sparepart sangat memerlukan sistem informasi untuk menunjang segala aktifitas pengolahan data dan informasi. Sistem adalah sekelompok unsur yang erat hubungannya satu dengan yang lain, yang berfungsi bersama-sama untuk mencapai tujuan tertentu (Sutabri, 2012). Informasi adalah Informasi adalah data yang diolah menjadi bentuk lebih berguna dan lebih berarti bagi yang menerimanya (Yakub, 2012). Salah satu perusahaan yang mengembangkan usahanya pada 
pelayanan jasa perbaikan atau usaha bengkel adalah Astra Motor Jakarta, Astra Motor Jakarta adalah sebuah bengkel yang menjual suku cadang serta melayani jasa service motor. Hal ini sesuai dengan pendapat (Sinambela, Litjan Poltak, 2011) yang menyatakan bahwa pelayanan adalah suatu kegiatan atau urutan kegiatan yang terjadi dalam interaksi langsung antar seseorang dengan orang lain atau mesin secara fisik, dan menyediakan kepuasan pelanggan tertentu.

Pada bengkel Astra Motor Jakarta, sistem informasi data service dan penjualan masih dilakukan dengan pencatatan menggunakan kertas, dengan kata lain belum menggunakan sistem yang terkomputerisasi. Sehingga banyak hambatan saat melakukan proses pengolahan data seperti data service dan data penjualan.

Oleh karena itu, untuk menyajikan informasi yang cepat dan akurat dalam proses pengolahan data harus dilakukan secara terkomputerisasi dalam sistem yang biasa di sebut sistem informasi. Hal ini sesuai dengan pendapat (Ladjamudin, 2013) yang mengatakan bahwa konsep dasar informasi yaitu bahwa informasi sebagai sebuah data yang telah dilakukan pengolahan manjadi suatu bentuk yang lebih berarti serta berguna bagi penggunanya dalam pengambilan keputusan baik untuk masa kini atau yang akan datang. Maka, sistem yang baik dalam suatu perusahaan akan mampu membuat perusahaan itu lebih maju dan berkembang, oleh karena itu setiap perusahaan perlu adanya penyesuaian sistem.

Tujuan penelitian ini adalah untuk merancang sebuah aplikasi sistem informasi pengolahan data penjualan sparepart dan service pada bengkel Astra Motor Jakarta Berbasis Java. Java adalah Java adalah bahasa pemrograman yang dapat dijalankan di berbagai perangkat komputer, termasuk pada ponsel (Kurniawan dkk, 2011). Hasil dari penelitian ini adalah aplikasi yang dapat Memberikan siklus sistem yang baru tentang proses pengolahan data sparepart dan service pada Astra Motor Jakarta serta memberikan laporan penjualan sparepart dan service dengan cepat dan akurat.

\section{PENELITIAN RELEVAN}

Penelitian yang dilakukan oleh (Rian Pujadi, 2018) Sistem Informasi Inventory Dan Penjualan Agen Aqua SBY Water Berbasis Java Desktop. Penelitian ini bertujuan untuk membuat sebuah sistem yang dapat pencarian produk Aqua akan lebih mudah dan memberikan informasi kepada pelanggan lebih cepat dibandingkan dengan pencarian produk Aqua dengan cara manual yaitu membuka dokumen persedian manual, dengan aplikasi ini diharapkan pelanggan lebih puas dalam pelayanan kami. Sehingga akan mendukung dalam pembuatan laporan persedian barang, barang masuk dan keluar serta retur penjualan lebih terperinci dibandingkan dengan cara manual, sehingga menghasilkan suatu laporan yang baik, akurat, dan cepat.

Penelitian yang dilakukan oleh (Susanti, 2013) Perancangan Sistem Informasi Penjualan dan Service Pada Bengkel Mobil JSP Yogyakarta. Penelitian ini bertujuan untuk mengidentifikasi masalah-masalah yang terjadi serta informasi apa saja yang dibutuhkan dalam sistem informasi pada bengkel JSP Yogyakarta dan untuk Merancang sistem informasi penjualan dan jasa bengkel JSP Yogyakarta yang terkomputerisasi.

Penelitian yang dilakukan oleh (Sukmana, 2014) Sistem Informasi Pengolahan Data Barang dan Service Komputer Pada Toko Sinar Terang Komputer Pacitan. Penelitian ini bertujuan untuk Menghasilkan sistem informasi pengolahan data barang dan service komputer pada Toko Sinar Terang Komputer Pacitan.

Penelitian yang dilakukan oleh (Aidah dkk, 2016) dengan judul Analisa dan Perancangan Sistem Informasi Penjualan Jasa Service Sepeda Motor dan Sparepart pada Bengkel Karya Sejahtera Motor. Tujuan penelitian merancang sistem informasi terkomputerisasi penjualan sparepart dan service pada Bengke Karya Sejahtera Motor,sehingga dapat mengoptimalkan pengolahan data yang lebih baik dari proses sedang berjalan saat ini. Hasil penelitian adalah dapat mamudahkan dalam mengolah data dan menguragi kesalahan dalam pembuatan laporannya serta memberikan informasi yang akurat, tepat untuk mengambil keputusan sehingga dapat berkompetisi dengan perusahaan lain 


\section{METODE PENELITIAN}

Metode penelitian yang digunakan oleh peneliti adalah metode grounded research. Metode grounded research yaitu suatu metode penelitian berdasarkan pada fakta dan menggunakan analisis perbandingan dengan tujuan mengadakan generalisasi empiris, menetapkan konsep, membuktikan teori, mengembangkan teori, pengumpulan dan analisis data dalam waktu yang bersamaan (Barnabas, 2018). Dalam riset ini data merupakan sumber teori atau teori berdasarkan data.

\section{Metode pengumpulan data}

Metode pengumpulan data yang digunakan sebagai berikut :

1. Metode Observasi, dengan cara mengadakan kunjungan langsung ke lapangan dimana dapat secara langsung mencatat hal-hal yang dirasa penting dan sesuai dengan masalah yang akan diambil. Untuk metode ini dilakukan dengan bimbingan dari perusahaan.

2. Metode Wawancara, dengan cara mengajukan beberapa peryanyaan secara langsung kepada Pak Rendra selaku kepala bengkel.

3. Metode Studi Pustaka, dengan cara mencari referensi melalui perpustakaan.

\section{HASIL DAN PEMBAHASAN}

\section{Analisis Permasalahan}

Setelah dianalisa ada beberapa kelemahan dari sistem informasi yang sedang berjalan, diantaranya:

1. Proses penjualan dan service yang masih belum terkomputerisasi, sehingga dalam pembuatan tanda bukti penjualan dan service masih manual.

2. Adanya kesulitan bagian partman untuk melakukan rekap data sparepart dan penjualan sparepart pada Astra Motor Jakarta.

3. Belum adanya aplikasi yang mendukung dalam proses pengaksesan sistem stok barang, penjualan, dan service di Astra Motor Jakarta secara terkomputerisasi.

\section{Alternatif Penyelesaian Masalah}

Setelah menganalisa dan mengevaluasi sistem yang sedang berjalan, maka sebagai tindak lanjut bagi penyelesaian masalah maka solusinya adalah:

1. Perlu adanya suatu aplikasi sistem penjualan dan service yang dapat memudahkan administrasi dalam pengecekan barang masuk, barang keluar, penjualan barang, dan pendaftaran service.

2. Dengan dibuatnya sistem aplikasi pengadaan barang dan penjualan yang terkomputerisasi diharapkan dapat memudahkan administrasi dalam melakukan pengecekan data barang masuk, barang keluar, dan penjualan sparepart di Astra Motor Jakarta yang diperlukan untuk membuat laporan.

3. Sistem aplikasi pengolahan dan penjualan dibuat dengan fasilitas login admin agar data menjadi aman.

\section{Aturan Bisnis Sistem yang Diusulkan}

Aturan sistem informasi pengolahan data penjualan sparepart dan service yang diusulkan pada Bengkel Astra Motor Jakarta sebagai berikut:

1. Admin, service advisor dan partman mempunyai autentikasi login yang berbeda untuk mengakses aplikasi sistem informasi penjualan dan service.

2. Kegiatan pengolahan data dan pembuatan laporan dilakukan secara terkomputerisasi.

3. Admin memiliki hak akses penuh dalam mengolah data user.

4. Service advisor hanya dapat mengakses fitur transaksi service, data mekanik, data kendaraan, dan melihat stok data sparepart pada sistem yang dirancang.

5. Partman hanya dapat mengakses fitur transaksi penjualan sparepart, data pemasok, dan menambah stok sparepart pada sistem yang dirancang. 


\section{Use Case Diagram}

\section{Identifikasi Aktor}

\section{Tabel 1. Identifikasi Aktor}

\begin{tabular}{cll}
\hline No & \multicolumn{1}{c}{ Aktor } & \multicolumn{1}{c}{ Deskripsi } \\
\hline 1 & Admin & Bertugas dalam pembuatan user akun dan menangani masalah sistem. \\
2 & Service Advisor & Bertugas menangani data mekanik, data pelanggan dan transaksi service. \\
3 & Partman & Bertugas menangani data pemasok, data stok sparepart serta penjualan \\
& & sparepart.
\end{tabular}

\section{Identifikasi Diagram Use Case}

\begin{tabular}{|c|c|c|c|}
\hline No & Use Case Name & Description & Actor \\
\hline 1 & Login & $\begin{array}{l}\text { Use case menggambarkan kegiatan } \\
\text { memasukkan } \text { username dan password. }\end{array}$ & $\begin{array}{l}\text { Admin, Service Advisor dan } \\
\text { Partman }\end{array}$ \\
\hline 2 & Menu Utama Admin & $\begin{array}{l}\text { Use case menggambarkan tampilan awal } \\
\text { menu admin. }\end{array}$ & Admin \\
\hline 3 & $\begin{array}{l}\text { Menu Utama Service } \\
\text { Advisor }\end{array}$ & $\begin{array}{l}\text { Use case menggambarkan tampilan awal } \\
\text { menu service advisor. }\end{array}$ & Service Advisor \\
\hline 4 & Menu Utama Partman & $\begin{array}{l}\text { Use case menggambarkan tampilan awal } \\
\text { menu partman. }\end{array}$ & Partman \\
\hline 5 & Data User Akun & $\begin{array}{l}\text { Use case menggambarkan data user untuk } \\
\text { login ke sistem. }\end{array}$ & Admin \\
\hline 6 & Data Mekanik & $\begin{array}{l}\text { Use case menggambarkan seluruh data } \\
\text { mekanik bengkel Astra Motor Jakarta. }\end{array}$ & Service Advisor \\
\hline 7 & Data Pelanggan & $\begin{array}{l}\text { Use case menggambarkan data pelanggan } \\
\text { pada bengkel Astra Motor Jakarta. }\end{array}$ & Service Advisor \\
\hline 8 & Data Kendaraan & $\begin{array}{l}\text { Use case menggambarkan data kendaraan } \\
\text { pelanggan yang ingin diservice. }\end{array}$ & Service Advisor \\
\hline 9 & Data Sparepart View & $\begin{array}{l}\text { Use case menggambarkan data sparepart } \\
\text { yang tersedia. }\end{array}$ & Service Advisor \\
\hline 10 & Transaksi Service Motor & $\begin{array}{l}\text { Use case menggambarkan data transaksi } \\
\text { service pada bengkel Astra Motor Jakarta. }\end{array}$ & Service Advisor \\
\hline 11 & Data Pemasok & $\begin{array}{l}\text { Use case menggambarkan data pemasok } \\
\text { yang telah bekerjasama dengan bengkel } \\
\text { Astra Motor Jakarta. }\end{array}$ & Partman \\
\hline 13 & Tambah Stok Sparepart & $\begin{array}{l}\text { Use case menggambarkan penambahan pada } \\
\text { stok sparepart. }\end{array}$ & Partman \\
\hline 14 & $\begin{array}{l}\text { Transaksi Penjualan } \\
\text { Sparepart }\end{array}$ & $\begin{array}{l}\text { Use case menggambarkan transaksi } \\
\text { penjualan sparepart. }\end{array}$ & Partman \\
\hline 15 & Report & $\begin{array}{l}\text { Use case menggambarkan report data } \\
\text { mekanik, data pelanggan, data kendaraan, } \\
\text { transaksi service, data pemasok, data } \\
\text { sparepart, tambah stok sparepart serta report } \\
\text { penjualan sparepart. }\end{array}$ & Service Advisor dan Partman \\
\hline 14 & Logout & $\begin{array}{l}\text { Use case menggambarkan kegiatan untuk } \\
\text { keluar dari sistem. }\end{array}$ & Service Advisor dan Partman \\
\hline
\end{tabular}


Jurnal Riset dan Aplikasi Mahasiswa Informatika (JRAMI)

Vol 03 No $\mathrm{Cl}$ Tahun 2022

e-ISSN : $2715-8756$

3. Use Case Diagram

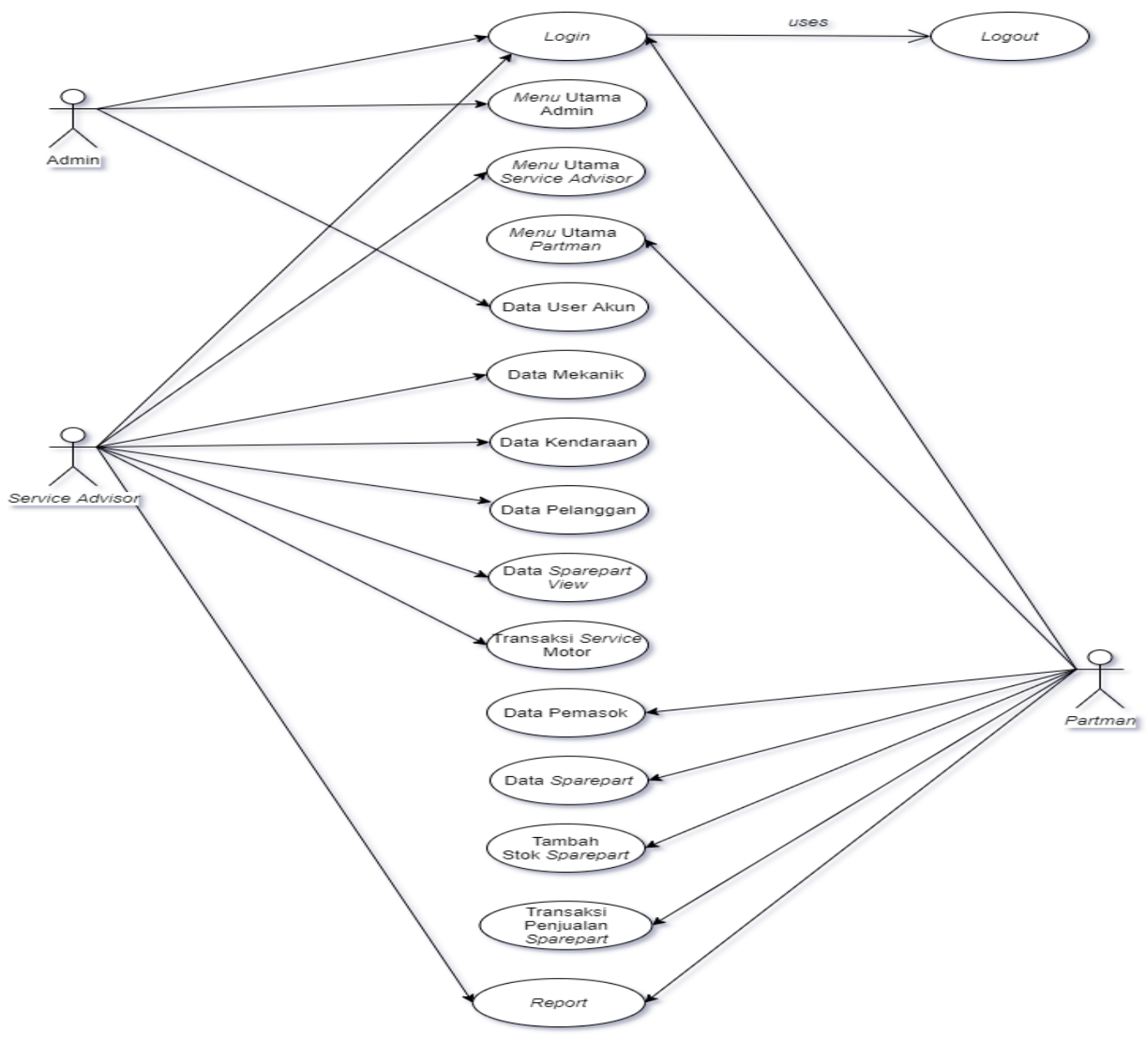

Gambar 1. Use Case Diagram

\section{Tampilan Aplikasi}

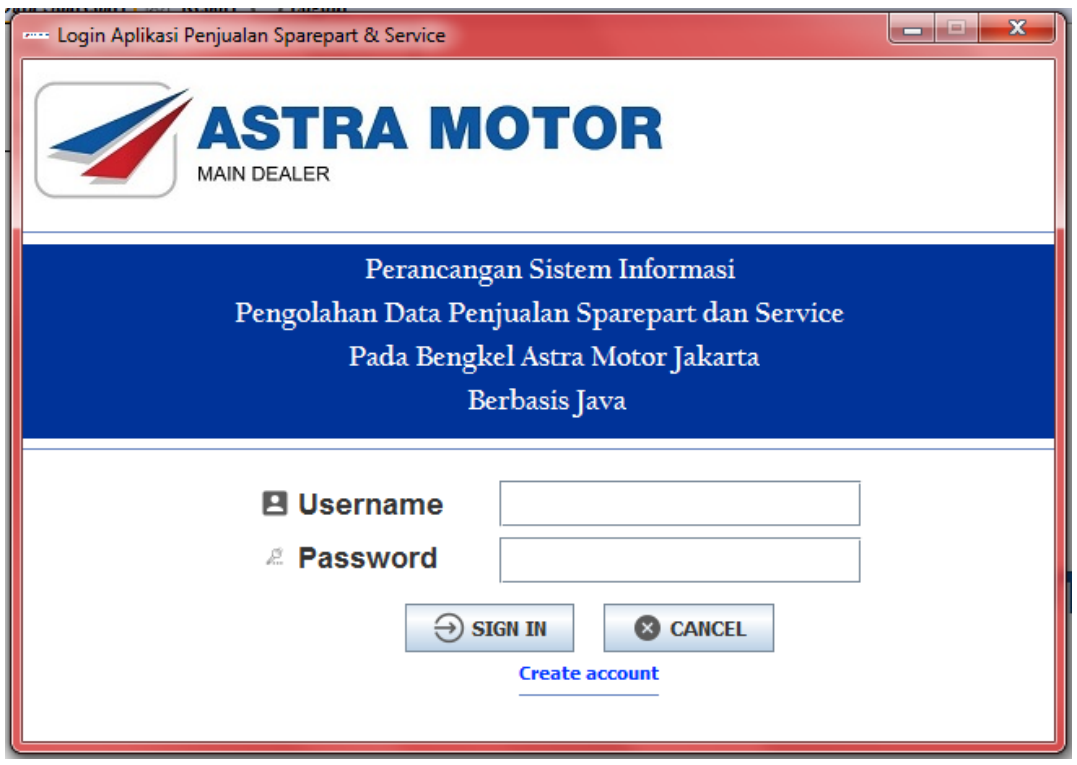

Gambar 2. Tampilan Form Login 
Halaman Login berguna untuk masuk ke dalam sistem sesuai dengan username dan password masing-masing account.

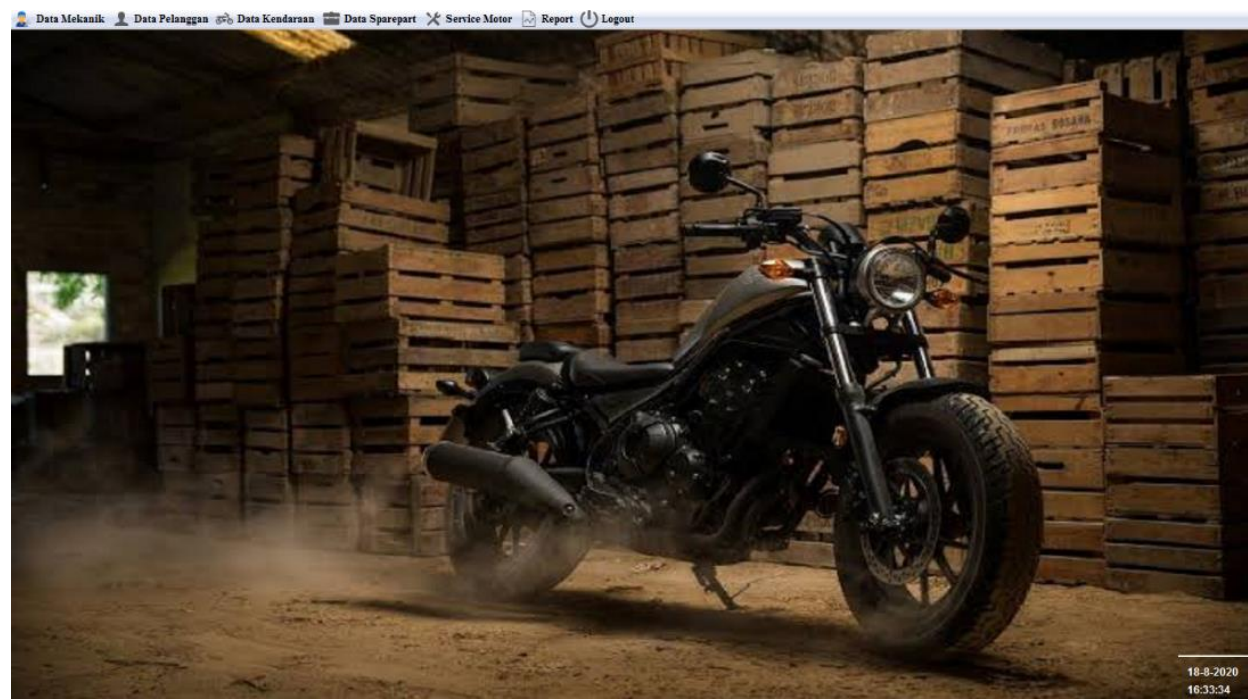

Gambar 3. Tampilan Menu Utama Service Advisor

Gambar diatas merupakan menu utama service advisor. Setelah service advisor berhasil login akan masuk ke menu utama service advisor, dalam menu utama service advisor terdapat beberapa menu lain diantaranya mеnu data mekanik, mеnu data pelanggan, mеnu data kendaraan, menu data view sparepart, menu transaksi service motor serta menu report.

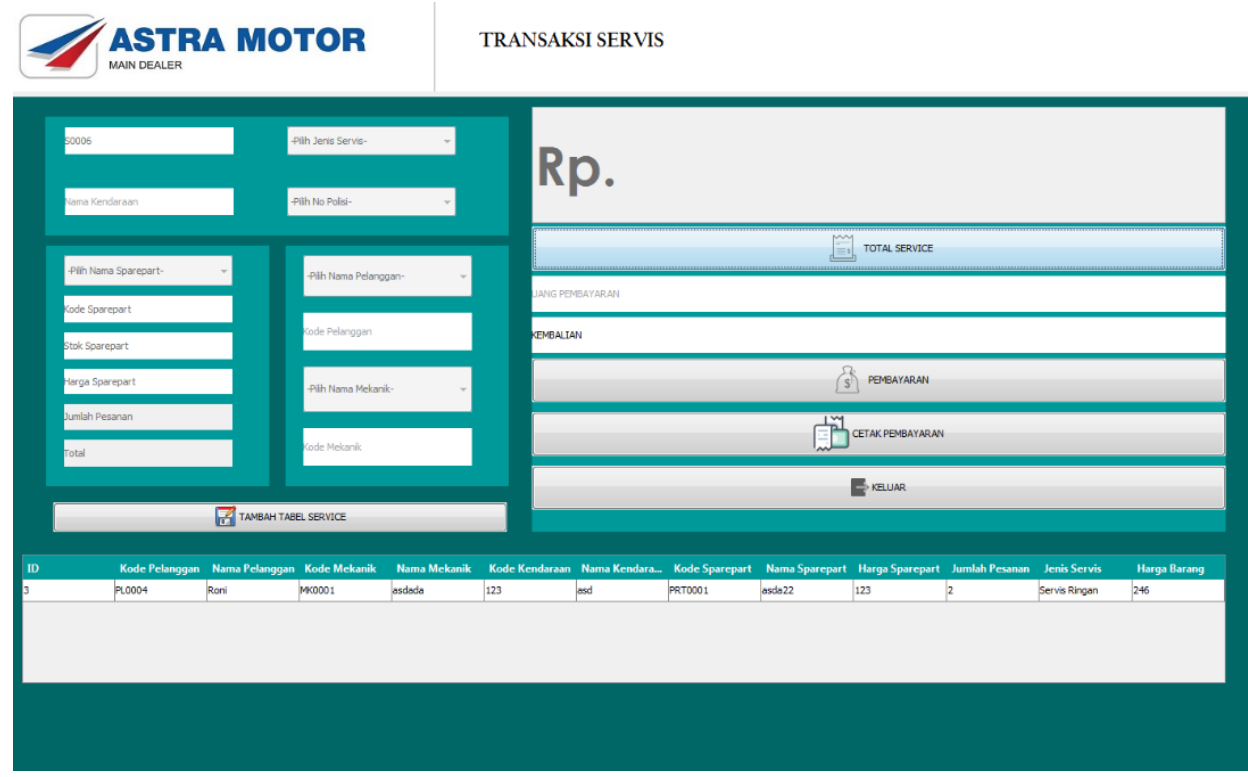

Gambar 4. Tampilan Form Input Transaksi Service Motor

Gambar diatas merupakan menu transaksi service motor. 


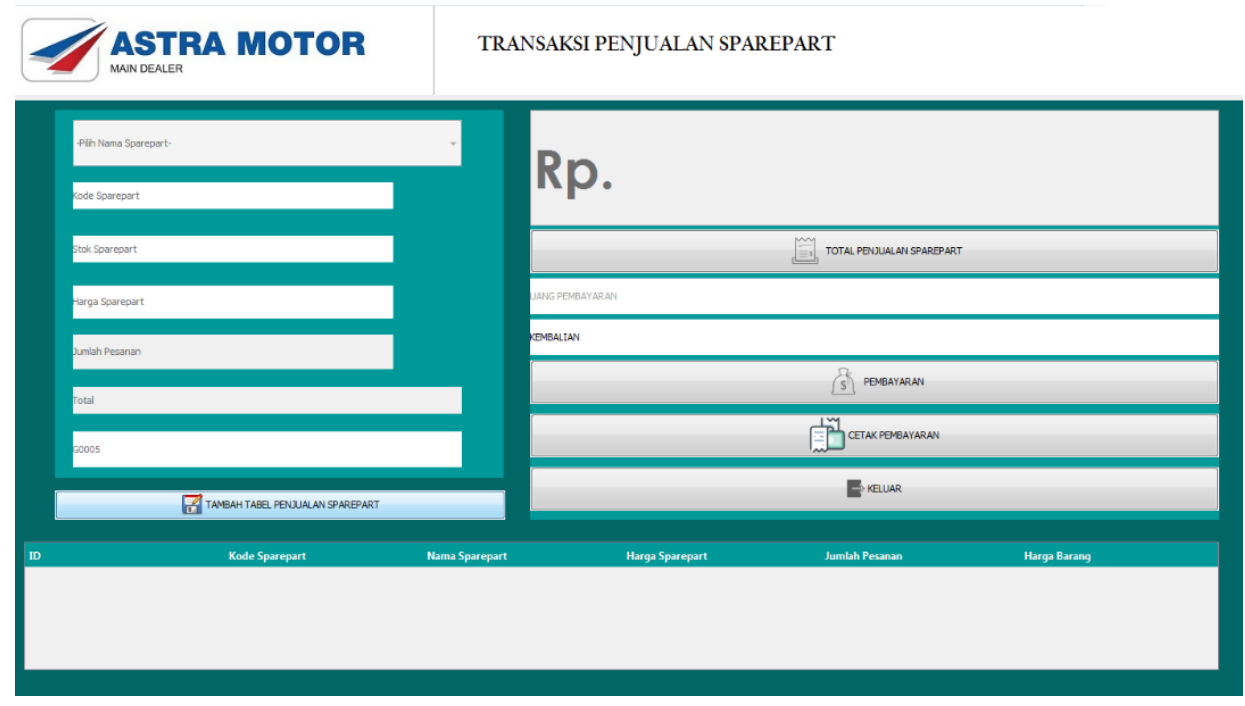

Gambar 5. Tampilan Form Input Transaksi Penjualan Sparepart

Gambar diatas merupakan menu transaksi penjualan sparepart.

\section{SIMPULAN}

Dengan dibuatnya Perancangan Sistem Informasi Pengolahan Data Penjualan Sparepart dan Service pada Bengkel Astra Motor Jakarta, semua kegiatan yang berhubungan dengan data mekanik, data pelanggan, data kendaraan, transaksi service motor, data pemasok, data sparepart, tambah stok sparepart, transaksi penjualan sparepart serta report tidak lagi secara manual. Dengan adanya jasa komputer sebagai alat bantu dan tenaga admin, tenaga service advisor serta tenaga partman sebagai user, peneliti memiliki kesimpulan dengan menggunakan sistem ini dapat memberikan keuntungan sebagai berikut:

1. Perancangan Sistem Informasi Pengolahan Data Penjualan dan Service Pada Bengkel Astra Motor Jakarta ini menggunakan desain penelitian grounded research dan untuk metode perancangan sistem yang digunakan yaitu: (a) Unified Modelling Language (UML) yang terdiri dari use case diagram, activity diagram, sequence diagram, class diagram, rancangan basis data. (b) Rancangan layar menggunakan aplikasi Microsoft Visio. (c) Penyimpanan data menggunakan MySQL dan untuk laporan menggunakan iReport. (d) Perancangan aplikasi menggunakan software NetBeans 8.0.2.

2. Evaluasi yang dilakukan dalam sistem ini adalah pengujian dengan menggunakan blackbox testing yang terdiri dari pengujian sistem level admin, pengujian sistem level service advisor dan pengujian sistem level partman. Serta untuk implementasi aplikasi menggunakan perangkat keras dan perangkat lunak untuk mendukung proses kerja dari sistem, sehingga program dapat digunakan untuk mempermudah pekerjaan.

\section{DAFTAR PUSTAKA}

Aidah, Winanti, \& Anugrah, R. (2019). Analisa Dan Perancangan Sistem Informasi Penjualan Jasa Service Sepeda Motor Dan Sparepart Pada Bengkel Karya Sejahtera Motor. Jurnal Insan Pembangunan Sistem Infomasi \& Komputer, (Vol 4 No 2), 1-6.

Barnabas, B. (2018). Grounded Research/GroundedTheory (Metode Penelitian Grounded).

Kurniawan, Hendra, Eri Mardiani dan Nur Rahmansyah. (2011). Aplikasi Penjualan dengan Program Java Netbeans, Xampp, dan iReport. Jakarta: PT Elex Media Komputindo.

Ladjamudin, A. B. (2013). Analisis dan Desain Sistem Informasi. Graha Ilmu.

Pujadi Rian. (2018). Sistem Informasi Inventory Dan Penjualan Agen Aqua SBY Water Berbasis Java Desktop.

Sinambela, Litjan Poltak, dkk. (2011). Pelayanan. PT. Bumi Aksara.

Sukmana, F. (2014). Sistem Informasi Pengolahan Data Barang Dan Service Komputer Pada Toko Sinar Terang Komputer Pacitan. Indonesian Journal on Networking and Security, 3(4), 52-58.

Sutabri, Tata. 2012. Analisis Sistem Informasi. Yogyakarta: Andi 
Jurnal Riset dan Aplikasi Mahasiswa Informatika (JRAMI)

Vol 03 № $\mathrm{Cl}$ Tahun 2022

e-ISSN : $2715-8756$

Susanti, R. (2013). Perancangan Sistem Informasi Penjualan dan Servis Pada Bengkel Mobil JSP Yogyakarta. Intoxicacion As Frecuentes Y Sus Principales Factores Influyentes En Niños Atendidos En El Servicio De Pediatria Del Hospital Provincial General Docente Riobamba Periodo Enero-Agosto Del 2013, 1, 80.

Yakub. (2012). Pengantar sistem informasi. Yogyakarta: Graha Ilmu 